\section{Curing the Infected Wound: Metaphor of State-Owned Enterprises in News Headlines}

\author{
1 Muhammad Adam
}

1 Universitas Balikpapan, Indonesia

\begin{abstract}
The current condition of Indonesian State Own Enterprises (SOEs) has become the focus of various studies across fields. The studies extend from an economic perspective to legal aspects, but the study to address the SOEs condition from linguistics perspective has been overlooked. On the other hand, the study of conceptual metaphor in media discourse puts little attention on this particular issue, and plenty of studies of conceptual metaphor do not account for the effect of contextual aspects on the additional inferences of metaphor. This study attempts to fill the gaps by examining the news headlines reports on the current conditions of SOEs using metaphorical expressions. It will take a closer look at the conceptual metaphor STATE-OWNED ENTERPRISES ARE PATIENTS in Indonesian news headlines and conducting further investigation on how contextual aspects influence the additional metaphorical inferences. The study is qualitative with purposive sampling method; the data taken are ten news headlines from online media news which discuss the current improvement process and condition of SOEs using metaphorical expressions. Conceptual Metaphor Theory (Lakoff \& Johnson, 1980) is the conceptual framework of this study. From ten news headlines analysed, three metaphorical framings to speak about the current condition of SOEs as if SOEs are patient, i.e.: SOEs is a sick patient with particular sickness, the government is a medical practitioner, and after treatment, SOEs is a healthy patient or a dying patient. The underlying conception of STATE-OWN ENTERPRISES ARE PATIENTS implies that there are still plenty outstanding actions to be taken to improve the SOEs' performance, not only to provide remedies but most importantly is to prevent the sickness.

Furthermore, additional inferences may emerge from the same metaphorical expressions in a different situational context. The implication is, media or journalists should consider that unintended inferences may arise from a particular metaphorical expression which are not initially meant to.
\end{abstract}

\section{Keywords}

conceptual metaphor

metaphor inferences

state-owned enterprises
Ethical Lingua

Vol. 7, No. 2, 2020

ISSN 2355-3448 (Print)

ISSN 2540-9190 (Online)

Corresponding Email

Muhammad Adam

adam@uniba-bpn.ac.id

Article's History

Submitted 11 June 2020

Revised 8 September 2020

Accepted 10 September 2020

DOI

10.30605/25409190.183

Copyright (๑) 2020

The Author(s)

This article is licensed under CC BY-NC-SA 4.0 License 


\section{Curing the Infected Wound: Metaphor of State- Owned Enterprises in News Headlines}

Indonesian State-Owned Enterprises (henceforth abbreviated as SOEs) ministry managed 142 Indonesian SOEs, and only fifteen enterprises have a good financial performance (Djailani, 2019). Since the new SOEs minister has officially took office, the minister's action on improving Indonesian SOEs has become one of the major discussions in media. Thus, the discussion on what actions to be taken by the minister and the description about the current condition of the SOEs has been a hot discussion in media financial discourses The discussion and the description of SOEs and the actions to be taken by the new state-own minister are often described in various metaphorical expressions, one of them is to speak about the enterprises as if the SOEs are patients who need medical treatments

This study is conducted within Conceptual Metaphor Theory (henceforth abbreviated as CMT) Framework (Lakoff \& Johnson, 1980) who agree that metaphor is not merely at language level, but beyond that, metaphor is located on the conceptual and cognitive level. The two main elements in CMT, the first is the source domain which is more concrete and the target domain which is more abstract is conventionally written in capital letters to differentiate it with metaphorical expressions.

Data from Indonesian news headlines describing SOEs conditions is used in this study. One of the linguistics features of news headlines is the use of various figurative languages, and metaphor is one of those. Another reason is the news headlines serve particular function in news presentation as asserted by Munro (2018) that headlines are a particularly powerful way in which key messages are conveyed to the reader, including those who do not go on to read the article in full or in-depth. The use of metaphorical expressions in news headlines will contribute to an extra power of news headlines and brings an extra effect to the reader as Hang (2016) affirms that as one of the common rhetorical devices, metaphor is common to be found in the front pages of newspapers that bring certain image effects to the readers' minds at the same time. Kövecses (2018) shares a similar opinion and affirms that contextinduced metaphor use in headlines is a common phenomenon as the headlines provide a clear pragmatic function, drawing the readers' attention and being sensational.

The use of metaphorical expressions in financial and economic discourse across languages have been highlighted by many scholars (Cardini, 2014; Gao, 2016; Langer, 2015). Cardini (2014) in particular, summarizes that one of the conceptual metaphor to be found in many studies is ECONOMY/FINANCE IS A HUMAN BEING, with the element of crisis mostly given by the fact that the person lacks physical or mental health (e.g. diseases, emotional distress); whereas Joris, d'Haenens \& Van Gorp (2019) focus on the effect of two most frequent of economy metaphorical frame of war and disease to participants. Hu \& Xu (2017) who study the use of war metaphor in Chinese Economic Media Discourse conclude that war metaphor has the power of persuasion, that trigger a conception of competition in the readers' mind, but hides the cooperative principle of economic activities in the other hand.

There are various studies focusing on Indonesian SOEs from economic focus of its management (Asnawi, 2016; Destria \& Norita, 2017; Ikhwansyah, Candrawulan, \& Amalia, 2018; Prajanto, 2019), this attention is because SOEs have a strategic role as public service administers the stabilizer of the private enterprises and are expected to support the 
development of small medium enterprises. SOEs are also one of the main source of states income (Juliani, 2018). Despite this interest, the linguistics aspect of news surrounding SOES is a neglected area. It is necessary to examine the use of SOEs metaphor within media discourse, as it will give a picture on how it is presented. Burr (1995) asserts on the definition of discourse as " a set of meaning, metaphors, representations, images, stories, statements, and so on that in some ways together a particular version of events surrounding any one object, event, person, etc., there may be a variety of different discourses, each with a different story to tell about the world, a different way of representing it to the world. Furthermore, studying this topic within conceptual metaphor framework is expectedly become a preliminary study into examining the narratives and discourse of SOEs in particular and in Indonesian economic in general.

This study then, is intended to serve the purpose highlighted above. Therefore, this study aims to examine the portrayal of the SOEs from linguistics perspective by focusing on the conceptual metaphor describing SOEs financial conditions by identifying the inferences of target domain (STATE-OWNED ENTERPRISES) that are mapped onto the source domain (PATIENTS) and the extended concepts related to patients in Indonesian news headlines.

Throughout this study, the conventional writing for conceptual metaphor mapping of source domain to target domain in capital letters is used.

\section{Method}

This study is qualitative study, there are ten news headlines from various online media news are taken as the data source. The headlines are chosen based on source domain-oriented by identifying the metaphorical expressions usage based on patients as the source domain, in this case, the headlines that contains metaphorical use of lexical unit related to the entities, properties and qualities of a patient and, is describing the state own enterprises as the target domain.

In Identifying metaphorical expressions, it cannot be based solely on researcher's intuition alone. Therefore, Metaphor Identification Procedure (MIP) (Group, 2007) is used to identify metaphorical expressions from news headlines.

After ten news headlines are collected, the data are categorized into three framing categories of a patient: (i) Sick patients; (ii) The medical treatment giver and the remedies given; and (iii) The patient's condition afterwards (whether recover or not). At data analysis stage, the filling in (framing) inferences (Suvorova \& Pulyakova, 2018) is the one that fits with uncovering inferences from metaphorical expressions. Researcher will carefully examines the entities, qualities, properties and functions associated with metaphorical words of the source domain then examine the entities, qualities, properties and functions that are found on the context of its use in headlines or in the target domain. Then, the comparison will be made.

Conceptual Metaphor Theory (CMT) is chosen as framework in this particular study since it enables a detail investigation of mapping across two involved domains in metaphorical expressions. Furthermore, using the CMT framework in this metaphor analysis of headlines is suitable since the study of the cognitive dimension of metaphor is a valuable tool in understanding how and why the media creates its messages in its various modalities (Kövecses, 2018). 


\section{Results \& Discussion}

The three-framing associated with "patient" are all found in the metaphorical expressions that projected the conceptual metaphor STATE-OWNED ENTERPRISES ARE PATIENTS. Various lexical units are used on each framing. During data analysis, the situational context surrounding the broadcasting of the news are also taken into account, as this will provide an access to identify the additional inferences of similar metaphorical expressions. The list of metaphorical expressions is presented on table 1 below:

Table 1. Conceptual metaphor STATE-OWNED ENTERPRISES ARE PATIENTS in news headlines

\begin{tabular}{|c|c|c|}
\hline No. & Headline & Metaphor \\
\hline 1 & $\begin{array}{l}\text { Diminta Erick Bosnya Tak Foya-foya, Ini Daftar BUMN 'Sakit' } \\
\text { (Wareza, 2019) }\end{array}$ & Sakit / Sick \\
\hline 2 & $\begin{array}{l}\text { Erick Thohir Akan Likuidasi BUMN 'Sakit' (CNN Indonesia, } \\
\text { 2019) }\end{array}$ & Sakit / Sick \\
\hline 3 & $\begin{array}{l}\text { Borok Jiwasraya Terbuka, 'Cacat' BUMN Satu per Satu } \\
\text { Terungkap (Ferry \& Wareza, 2020) }\end{array}$ & $\begin{array}{l}\text { Borok / Infected Wound } \\
\text { Cacat / Impaired }\end{array}$ \\
\hline 4 & $\begin{array}{l}\text { Jiwasraya Buka Kotak Pandora, 'Borok' BUMN Terbuka Lebar } \\
\text { (Saragih, 2020) }\end{array}$ & Borok / Infected Wound \\
\hline 5 & Obati 10 BUMN Sakit, Begini Strategi Jitu PPA (Wareza, 2019) & Obati / to cure \\
\hline 6 & $\begin{array}{l}\text { Genjot Infrastruktur, Pemerintah Suntik Modal ke } 8 \text { BUMN } \\
\text { (Astutik, 2019) }\end{array}$ & Suntik / to inject \\
\hline 7 & $\begin{array}{l}\text { Daftar } 7 \text { BUMN yang tetap rugi meski sudah disuntik PMN } \\
\text { (Idris, 2019) }\end{array}$ & Disuntik / to be injected \\
\hline 8 & $\begin{array}{l}\text { PPA Rawat Sembilan BUMN Sakit, Dua Sudah Sehat } \\
\text { (Anggraeni, 2019) }\end{array}$ & $\begin{array}{l}\text { Rawat / to treat } \\
\text { Sehat / Fit }\end{array}$ \\
\hline 9 & $\begin{array}{l}\text { Merpati Yang Hidup Lagi Setelah } 5 \text { Tahun Mati Suri (Aria, } \\
\text { 2019) }\end{array}$ & Mati suri / Apparent Death \\
\hline 10 & $\begin{array}{l}\text { Ini Deretan BUMN Sekarat Yang Mau Ditutup Erick Thohir } \\
\text { (Afriyadi, 2020) }\end{array}$ & Sekarat / Dying \\
\hline
\end{tabular}

Details of each metaphorical framing of metaphorical expressions where SOEs are described as sick patients are discussed in detail in the following sub-section:

\section{State-Owned Enterprises Are Sick Patients}

The word "sick" as metaphorical expressions is used to describe SOEs as presented in headline (1) and headline (2) below, the word sakit (sick) is used to describe condition of state owned-enterprises:

(1) Diminta Erick Bosnya Tak Foya-foya, Ini Daftar BUMN 'Sakit' (Wareza, 2019)

Erick asks the state-owned enterprises not to waste money, this is the list of the sick stateowned enterprises. 
The headline (1) above is about the minister Erick Thohir who asks that all the board of directors of state-owned enterprises with a struggling financial condition not to spend money for unofficial purposes. The headline described the list as the 'sick' (sakit) SOEs.

The context situation of the news emerged from the minister who expresses his disappointment after he was invited by executives and board of directors to have dinner at luxury restaurant. Having dinner in a fancy restaurant amid struggling financial conditions is considered an insensitive action. Based on the list from the news, there are ten state-own enterprises that are under supervision of PT. Perusahaan Pengelola Aset (PPA) - Asset Management Company. Those 10 companies are under supervision for a poor balance sheet (Wareza, 2019), one of them is even on the process to file bankruptcy.

The same word is used in headline (2) below,

(2) Erick Thohir Akan Likuidasi BUMN 'Sakit' (CNN Indonesia, 2019)

Erick Thohir (SOEs Minister) will liquidate the sick SOEs

In headline (2) above, the context of the news is about the plan of the minister of SOEs -Erick Thohir- to shut down the state-owned enterprises that are under supervision by the PPA.

The framing of 'sick' (sakit) is the condition that will not allow someone to normally perform their activities due to a poor health condition, triggers inferences as below:

1. A Sick person has a health problem

2. A sick person needs a medical treatment

3. A sick person is not physically or mentally fit

These inferences can be mapped onto the target domain state own enterprises to imply:

1. State-owned enterprises has a financial problem

2. They need government support to help

3. The enterprises are not normally operated due to financial condition.

Further inferences implied from a "sick patient" is the type of sickness or wound. In the headline (3) below, the type of sickness faced by the sick patient is described by using 'infected wound' (borok)

(3) Borok Jiwasraya Terbuka, 'Cacat' BUMN Satu per Satu Terungkap (Ferry \& Wareza, 2020)

Jiwasraya's infected wound is opened, SOE's impairment is one by one uncovered.

Jiwasraya is a state own insurance company fails to pay the due saving plans of its costumer and cause the insurance company into a further investigation for an unlawfully business conduct. Infected wound (borok) infers a negligence to treat the wound at initial stage that further cause a worse condition. When it refers to Jiwasraya's condition, it can be understood as a negligence on its management from the beginning and are continue for a long period of time. Whereas 'impairment' (cacat) as a physical inability that is used to describe other similar SOE's infers that the relatively similar condition to the similar insurance company, which apparently also have the same problem. 
1. It is a wound that happened long before but is not treated well and earlier

2. The wound might become worse if there is no medical treatment is given and will take longer to cure

3. The negligence of the wounded person contributes to the wound become infected.

The metaphorical inferences that can be withdrawn from 'infected wound' (borok) in this context is:

1. Jiwasraya failure to meet its obligation has happened for a long period of time

2. There will be worse failure if there is no action taken

3. The unawareness to the problem of Jiwasraya has made the failure worse overtime.

In headline (4) below, the same message is conveyed by using the word 'infected wound' (borok)

(4) Jiwasraya Buka Kotak Pandora, 'Borok' BUMN Terbuka Lebar (Saragih, 2020)

Jiwasyara opens Pandora box, state-owned enterprises' infected wounds are widely opened.

There are two metaphorical expressions from the headline (2) above, the first one is how Jiwasraya is understood as a person who opens the pandora box (kotak Pandora). The use of the 'pandora box' activate a frame that a bad thing is released, whereas the second metaphorical expressions is SOES infected wound (borok BUMN)

The context of the news in headline (3) and headline (4) above are the same, where the failure for payment of costumers' saving plan cause an inquiry and investigation of misconduct in Jiwasraya. This problem then reveals a further awareness that there are many other similar state own insurances might have the same problem.

In headline (3), Jiwasraya is the one who has the infected wound, whereas in headline (4), the other SOEs that are struggling financially are having the infected wound. Those SOEs are Asabri, Krakatau Steel, Garuda Indonesia and Pos Indonesia. (Saragih, 2020)

The inferences of infected wound (borok) in literal word is the same, but the metaphorical inferences based on the context in headline (4) is different from headline (3).

The metaphorical inferences that can be withdrawn in headline (4) is

1. Those financially struggling SOEs are struggling financially and has happened for a long period of time

2. There might be worse failure if there is no action taken

3. The unawareness of the problem to those insurance companies has made the failure worst overtime.

The most dominant inferences is the long problem that has happened before, late to handle and a further worst problem might occur if there is no action to cure the wound. Another additional image from the metaphor using infected wound is that the process will be more complicated than the normal one.

The word 'infected wound' (borok) itself will bring negative inferences as it refers to an open wound that is infected and trigger disgust. It also associates with improper things that are hidden. The use of 'infected wound' (borok) as metaphorical expressions to describe the SOEs condition, especially in headline (3) and headline (4) above suggests that all of the financial 
loss and misconduct has been hid for a long period of time. In particular to headline (4) above, the use of 'pandora box' (Kotak Pandora) reinforces the entailments that something improper is hidden, and the last additional entailments of the word 'infected wound' (borok) is there must be someone who should've been responsible to treat the wound, but didn't do it, that eventually become infected.

The sick patient condition triggers further entailments, such as who will give a medical treatment and what types of remedies given. These framing are also used to describe the SOEs condition and the one who responsible for the medical treatment

\section{Government is a Doctor and Investment is Remedy}

The description of state own enterprises as a (sick) patient is also accompanied with the relevant related frame of that a sick patient should be taken care, be treated medically and be given remedies.

In headline (5) to headline (8) below, various metaphorical expressions are used to describe the actions and the financial support that are given to SOEs using verb from that infer a medical treatment process.

Although government and Asset Management Company (PPA) are not explicitly described in analogy using other terms, but the implied suggest that the role it plays is as a medical practitioner.

(5) Obati 10 BUMN Sakit, Begini Strategi Jitu PPA (Wareza, 2019)

Giving Medication to State-Owned Enterprises, This is PPA strategy.

Asset Management Company (PPA) is the company that is appointed by the government to handle and to supervise the financially struggled SOEs.

The framing of 'to cure' (obati) triggers the following inferences:

1. There is a sick patient

2. The sick patient need medical attention

3. Doctor or Medical Practitioner will give the treatment.

The context of the news is the actions that will be taken by PPA to support the state-own enterprises improve the financial performances by some strategies described. Based on the context and the metaphorical inferences are:

1. There are state owned enterprises in a poor performance

2. These enterprises need improvement and support from PPA

3. PPA will provide strategies to support the enterprises.

Whereas in headline (6) below, the headline describes government, in this context- the ministry of treasury as the medical doctor by using the word 'to inject' (suntik), to describe the action taken by the government to invest more capital to state-owned enterprises.

(6) Genjot Infrastruktur, Pemerintah Suntik Modal ke 8 BUMN (Astutik, 2019)

Improve infrastructure, Government to inject investment to 8 SOEs 
'to inject' (suntik) infers a medical treatment which will be given to a sick patient, it also infers that the injection will be performed by a medical practitioner.

The context of the news is the government's action to give more financial support to eight state own enterprises in construction field to support them to improve the infrastructure projects development. Based on the context the metaphorical expressions inferences are:

1. A medical practitioner performs it to a sick patient (penetrating a fluid medication)

2. A procedure to treat the patient

3. After the procedures, patient is expected to recover

Based on the context of the news, the inferences of the metaphorical expressions are not perfectly match as the eight state-own enterprises mentioned are not on poor financial conditions, the capital investment from the government is intended to support the enterprises in building infrastructure, that are not in financially struggled condition.

Thus, the metaphorical inferences in headline (6) above are not fully mapped onto the metaphorical inferences, the dominant inferences emerged is the procedure only, since, the additional inferences from the word 'to inject" is performing medical fluid penetration using a syringe. This is parallel with how money is always metaphorically express as a fluid and something liquid. Therefore, by using to inject, it is only to infer the action of giving capital investment but is not intended to infer that this is a procedure to treat a financially poor stateown enterprises.

Different from headline (6) above, the three inferences of 'suntik' / to inject has a more complete mapping based on the context of the news in headline (7) below:

(7) Daftar 7 BUMN yang tetap rugi meski sudah disuntik PMN (Idris, 2019)

The list of 7 SOEs which are still financially lost, even it has been 'injected' with national investment.

The news refers to seven SOEs who are in financial loss, and based on the inferences of the word 'being injected' (disuntik), the metaphorical inferences are:

1. A medical practitioner performs it to a sick patient is mapped to the government action by giving investment

2. A procedure to treat the patient is mapped to the financial support of investment to the financially loss SOES

3. After the procedures, patient is expected to recover which in this context also mapped into the expectation for an improved performance.

From the context, particularly from the last inferences, the recovery process fails of the SOEs fail, even though there has been a capital investment from the government.

In the headline (8) below, there are three words used that used metaphorically which support the complete framing of the SOEs are sick patients, from the treatment process, the doctor, the sick condition and the recovery process.

(8) PPA Rawat Sembilan BUMN Sakit, Dua Sudah Sehat (Anggraeni, 2019)

PPA treats nine 'sick' SOEs, two of them have been in 'fit condition' 
The context of the news refers to the improvement process conducted by PPA to nine SOEs, and from those nine SOEs, two of them has been financially improved and perform well that is described as 'fit' (sehat) condition. The inferences from the metaphorical expressions in headline (8) are mapped completely to the target domain, as it describes all the entities, attributes and properties of the whole process that are performed to a sick patient, in this context, to the SOEs.

The process of SOEs improvement, apparently is not always progress well as expected. As seen from headline (7), where the SOEs which has been given capital investment has not shown any improvement. When the progress of improvement are not fulfill the expected performance, the metaphorical expressions are also used as to describe a sick patient with no positive progress as seen in the next sub-section.

\section{Financially Struggled SOEs are Dying Patients}

When a sick patient is not recover, then it will potentially facing death. This framing is shown from the two headlines that describe how some state own enterprises close to bankruptcy.

(9) Merpati Yang Hidup Lagi Setelah 5 Tahun Mati Suri (Aria, 2019)

Merpati alive again after 5 years of apparent death.

Headline (9) above is about one of state-owned airline, Merpati Indonesia, which has ceased its operation since 5 years ago due to financial problem, The cease operation condition is metaphorically described as 'apparent death' (mati suri), whereas the improved condition and starts to operate again is described as 'hidup lagi'(alive again)

'Apparent death' triggers inferences:

1. Inactive bodily function

2. A very small chance to live again

And when it used to describe the SOES condition, the metaphorical inferences in the context of Merpati airlines are :

1. No operation

2. Need radical actions to improve all aspects of the company to be able to operate again.

The improvement plan from the government to bring the airline back into business is metaphorically described as 'alive again'(hidup lagi).

In headline (10) below, the headline describes the action that will be taken by the SOEs minister to close down the financially struggling SOEs.

(10) Ini Deretan BUMN Sekarat Yang Mau Ditutup Erick Thohir (Afriyadi, 2020)

These are the dying SOEs to shut down by Erick Thohir.

The inferences from the word 'dying' (sekarat) is close to a death condition, and when it is use to describe the SOEs that are going to be closed down, it infers that there will be no chance to save these SOEs and the only option is to close them down. The use of sekarat/dying to describe those SOEs also entails those SOEs are struggling financially and have poor performance. 


\section{The Conceptual Mapping and Negative Inferences}

The metaphorical expressions arise from the conceptual metaphor STATE-OWNED ENTERPRISES ARE PATIENT extends not only from the sick condition itself, but also the framing that are conceptually related to a sick patient. With the application of conceptual theory of metaphor, the ontological correspondence or mapping of Source Domain to Target domain can be summarized as follows:

Table 2. The Mapping of Source Domain to Target Domain

\begin{tabular}{ll}
\hline Source Domain: PATIENT & Target Domain: STATE OWN ENTERPRISES \\
\hline $\begin{array}{l}\text { Physical Condition: } \\
\text { Sick (Sakit) }\end{array}$ & $\begin{array}{l}\text { Financially Struggling / Loss } \\
\text { Not operate }\end{array}$ \\
\hline Apparent Death (Mati Suri) & \\
\hline Sickness & $\begin{array}{l}\text { Poor financial performance due to misconduct } \\
\text { (In business practice and others) }\end{array}$ \\
Impairment (Cacat) & Various Problems in State-Own Enterprises \\
\hline Medical Treatment & \\
To cure (Obati) & To give investment \\
to inject, being injected (Suntik, disuntik) & To give investment (by government) \\
\hline Medical Practitioner & PPA and Government (Ministry of Treasury) \\
\hline The Treatment Result & To Give Capital Investment \\
Fit (sehat) & Financially well / gain profit \\
Dying (Sekarat) & Near bankruptcy \\
Alive again (Hidup lagi) & Back to business operation \\
\hline
\end{tabular}

Most of the inferences on each metaphorical expression are mapped onto the target domain. Nevertheless, there are inferences from the literal word that could emerge as negative and unintended inferences.

In the context of headline (6): the word 'to inject' (suntik) will infer that the eight SOEs are in poor financial conditions where in fact, they are not.

(6) Genjot Infrastruktur, Pemerintah Suntik Modal ke 8 BUMN (Astutik, 2019)

Improve infrastructure, Government to inject investment to 8 SOEs

The only properties of 'to inject' that is used to map the investment from the government is related to how a financial budget are commonly described in metaphor as a fluid.

Another metaphorical expressions which may raise the unintended inferences is from the use of word 'infected wound' (borok), as used in headline (3) and headline (4) which suggest there has been negligence and recklessness that result the infected wound. It then leaves an 
entailment of who is responsible for the negligent in this particular case, the question that can only be answer by the economic experts.

The use of metaphorical expressions to describe the SOEs current condition as patient with its sickness, and further followed by the need of medical treatment, and the result of treatment afterwards, imply an underlying conception of SOEs condition. Furthermore, there is a vivid message from the news headlines on giving a concrete description. For readers, it will surely be easier to understand the condition of SOEs and what actions are taken by the government when it is described with a concept that is easily to understand. Such as, what should be the medication and kinds of treatment to be given to a "sick" SOE which is interpreted literally to one the government plan and strategy, who shall be a medical practitioners, which is interpreted literally as which institution should be involved in the improvement process.

\section{Conclusion}

This study investigates conceptual metaphor STATE-OWNED ENTERPRISES ARE PATIENTS in news headlines that describe the current condition of state-owned enterprises including the government's action. From the result, the use of the conceptual metaphor STATE-OWNED ENTERPRISES ARE PATIENTS is expressed in metaphorical expressions that fulfill the complete framing of a sick patient, from the sickness, the need for a doctor and medical treatment, and the possible outcome of the treatment, whether recover or worse. The mapping analysis shows there are additional metaphorical inferences occurred as an effect of the contextual aspect of the news.

The metaphorical inferences that are intended by the producer (in this case media journalist) cannot be taken for granted that it will get through the readers as it is, that the interpretation will exactly the same. There could be additional inferences from a particular metaphorical expression affected from contextual aspects including social and cultural entailments of the specific words that is used. Using metaphorical expressions in news headlines is of course will add a powerful impact to draw attention of the readers, nevertheless, media or journalists should consider the possibilities of an extended inferences embedded in particular metaphorical expressions that may cause the misinterpretation of the whole message

Describing the financially struggled SOEs as patient implied the need of continuous support from the government, not only to provide remedies and medical treatments in form of investment, but also to identify the sickness in order to be able to prevent the reoccurrence.

Further research should be conducted on cross linguistics comparison of the use of metaphorical expressions in another language to investigate whether the target domain of economic institution condition is described in similar source domain.

\section{Acknowledgment}

I would like to express my appreciation to LPPM of Universitas Balikpapan who has conducted few research writing workshops that has bring motivation for conducting research and writing scientific articles. 


\section{References}

Afriyadi, A. D. (2020, February 20). Ini Deretan BUMN Sekarat Yang Mau Ditutup Erick Thohir. Detik.com. Retrieved from https://finance.detik.com/berita-ekonomi-bisnis/d4907400/ini-deretan-bumn-sekarat-yang-mau-ditutup-erick-thohir. Accessed February 21,2020

Anggraeni, R. (2019, October 24). PPA Rawat Sembilan BUMN Sakit, Dua Sudah Sehat. Sindonews.com. Retrieved From https://ekbis.sindonews.com/read/1451968/34/pparawat-sembilan-bumn-sakit-dua-sudah-sehat-1571905626. Accessed February 1, 2020.

Aria, P. (2019, October 17). Merpati Yang Hidup Lagi Setelah 5 Tahun Mati Suri. Katadata.co.id. Retrieved from https://katadata.co.id/berita/2019/10/17/merpati-yanghidup-lagi-setelah-5-tahun-mati-suri. Accessed February 1, 2020.

Asnawi, M. I. (2016). Implikasi Pengelolaan Bumn Persero Dalam Kerangka Welfare State Berdasarkan Mekanisme Perseroan Terbatas. Jurnal Hukum Samudra Keadilan, 11(1). 126-144. https://ejurnalunsam.id/index.php/jhsk/article/view/32

Astutik, Y. (2019, September 27). Genjot Infrastruktur, Pemerintah Suntik Modal ke 8 BUMN. CNBC Indonesia. Retrieved from https://www.cnbcindonesia.com/market/20190927145937-17-102717/genjotinfrastruktur-pemerintah-suntik-modal-ke-8-bumn. Accessed February 2, 2020

Burr, V. (1995). An Introduction to Social Constructionism. London: Routledge.

Cardini, F. (2014). Analysing English metaphors of the economic crisis. Lingue E Linguaggi, 11, 59-76. https://doi.org/10.1285/i22390359v11p59

CNN Indonesia. (2019, December 23). Erick Thohir Akan Likuidasi BUMN 'Sakit'.CNN Indonesia. Retrieved From https://www.cnnindonesia.com/ekonomi/2019122307510092-459235/erick-thohir-akan-likuidasi-bumn-sakit. Accessed on February 3, 2020

Destria, N. \& Norita, N. (2017). Analisis Kondisi Keuangan Sebelum Dan Sesudah Melakukan Akuisisi. e-Proceeding of Management, 4(1). 327-334. Retrieved January 20, From https://openlibrary.telkomuniversity.ac.id/pustaka/123621/analisis-kondisi-keuangansebelum-dan-sesudah-melakukan-akuisisi-studi-kasus-pada-pt-hutama-karyamengakuisisi-pt-istaka-karya-.html

Djailani, M. F. (2019, December 2). Erick Thohir Lapor DPR, dari 142 BUMN Hanya 15 yang Rajin Setoran. Retrieved from https://www.msn.com/id-id/ekonomi/ekonomi/erickthohir-lapor-dpr-dari-142-bumn-hanya-15-yang-rajin-setoran/ar-BBXCpb3?li=AAfuAgL. Accessed on January 20, 2020.

Ferry, S. \& Wareza, M. (2020, January 30). Borok Jiwasraya Terbuka, 'Cacat' BUMN Satu per Satu Terungkap. CNBC Indonesia. Retrieved from https://www.cnbcindonesia.com/market/20200130114824-17-133931/jiwasraya-bukakotak-pandora-borok-bumn-terbuka-lebar. Accessed on February 52020

Gao, L. (2016). A Comparative Study of Conceptual Metaphors in English and Chinese Economic News Headlines. Creative Education, 7(17) 2629-2639. https://doi.org/10.4236/ce.2016.717247

Group, P. (2007). MIP: A Method for Identifying Metaphorically Used Words in Discourse. Metaphor and Symbol, 22(1), 1-39. https://doi.org/10.1080/10926480709336752

Hang, N. T. (2016). Sport Metaphors in Political News Headlines. VNU Journal of Science: Foreign Studies, 32(2), 12-20. Retrieved from https://js.vnu.edu.vn/FS/article/view/1538

Hu, C. \& Xu, Y. (2017). WAR Metaphor in the Chinese Economic Media Discourse. Higher Education Studies, 7(1). 94-106. https://doi.org/10.5539/hes.v7n1p94 
Idris, M. (2019, December 21). Daftar 7 BUMN yang tetap rugi meski sudah disuntik PMN. Kompas.com. Retrieved from https://money.kompas.com/read/2019/12/21/142657926/daftar-7-bumn-yang-tetaprugi-meski-sudah-disuntik-pmn?page=all. Accessed on February 3. 2020

Ikhwansyah, I., Candrawulan, A., \& Amalia, P. (2018). Optimalisasi Peran Badan Usaha Milik Negara (BUMN) pada Era Masyarakat Ekonomi Asean (MEA). Jurnal Media Hukum, 25(2). 150-161. https://doi.org/10.18196/jmh.2018.0110.150-161

Joris, W., d'Haenens, L., \& Van Gorp, B. (2019). The effects of metaphorical frames on attitudes: The Euro crisis as war or disease? Communications, 44(4). 447-468. https://doi.org/10.1515/commun-2018-2021

Juliani, H. (2018). Aspek Yuridis Transformasi Hukum Keuangan Publik Ke Keuangan Privat Terhadap Pengelolaan Kekayaan Negara Yang Dipisahkan Pada BUMN. Administrative Law \& Governance Journal, 1(1), 25-43. https://doi.org/10.14710/alj.v1i1.25-43

Kövecses, Z. (2018). Metaphor In Media Language And Cognition: A Perspective From Conceptual Metaphor Theory. LEGE ARTIS Language Yesterday, Today, Tomorrow, III(1). https://doi.org/10.2478/lart-2018-0004

Lakoff, G., \& Johnson, M. (1980). Metaphors we live by. Chicago, IL: University of Chicago Press.

Langer, T. (2015). Metaphors in Economics: Conceptual Mapping of Possibilities in the Lecture of Economics. Procedia Economics and Finance, 25. 308-317. https://doi.org/10.1016/S2212-5671(15)00741-8

Munro, M. (2018) House price inflation in the news: a critical discourse analysis of newspaper coverage in the UK. Housing Studies, 33(7). 1085-1105. https://doi.org/10.1080/02673037.2017.1421911

Prajanto, A. (2019) Analisis Tingkat Kesehatan Bumn Sebagai Dampak Kebijakan Akuntansi ISAK 8 (Studi Kasus PT PLN Persero Tahun 2012 - 2017). Accounting Global Journal, 3(1). 1-13. https://doi.org/10.24176/agj.v3i1.3092

Saragih, H. P. (2020, January 30). Jiwasraya Buka Kotak Pandora, 'Borok' BUMN Terbuka Lebar.CNBC Indonesia. Retrieved From https://www.cnbcindonesia.com/market/20200130114824-17-133931/jiwasraya-bukakotak-pandora-borok-bumn-terbuka-lebar. Accessed on February 3, 2020.

Suvorova, E. V., \& Pulyakova, L. S. (2018). Types of Inferences in Discourse. Arab World English Journal (AWEJ), 9(1). 294-306. https://doi.org/10.24093/awej/vol9no1.21

Wareza, M. (2019, November 15). Obati 10 BUMN Sakit, Begini Strategi Jitu PPA. CNBC Indonesia. Retrieved from https://www.cnbcindonesia.com/market/2019111513195417-115549/obati-10-bumn-sakit-begini-strategi-jitu-ppa. Accessed on February 3, 2020.

Wareza, M. (2019, November 20). Diminta Erick Bosnya Tak Foya-foya, Ini Daftar BUMN 'Sakit'. CNBC Indonesia. Retrieved from https://www.cnbcindonesia.com/news/20191120135240-4-116595/diminta-erickbosnya-tak-foya-foya-ini-daftar-bumn-sakit. Accessed on February 3, 2020. 